http://jmscr.igmpublication.org/home/ ISSN (e)-2347-176x ISSN (p) 2455-0450

crossref DOI: https://dx.doi.org/10.18535/jmscr/v7i9.124

Journal Of Medical Science And Clinical Research

Original Article

\title{
Correlation of Serum Vitamin B 12 with Red Cell Indices and Hemoglobin in Indian Women in Second and Third Trimester of Pregnancy
}

\author{
Authors \\ Shiv Pankaj Khanna, MD ${ }^{1}$, Rigvardhan, $\mathrm{MD}^{2^{*}}$, Anisha Aggarwal ${ }^{3}$ \\ ${ }^{1}$ Associate Professor, Department of Pathology, Maharshi Markandeshwar Institute of Medical sciences \\ and Research, Mullana (Ambala-Haryana) \\ ${ }^{2}$ Professor, Department of Pathology, Saraswati Medical college, Unnao (UP) \\ ${ }^{3}$ Asst Professor, Dept of Community Medicine, Maharshi Markandeshwar Institute of Medical sciences and \\ Research, Mullana (Ambala-Haryana) \\ Maharshi Markandeshwar Institute of Medical sciences and Research, Mullana (Ambala-Haryana) \\ *Corresponding Author \\ Dr Rigvardhan \\ Professor, Dept of Pathology, Saraswati Medical College, Unnao - 209859; India
}

\begin{abstract}
Introduction: To determine serum vitamin B 12 in pregnant women in India in second or third trimester and its correlation with red cell indices in order to determine an inexpensive screening tool to ascertain vitamin B 12 deficiency.
\end{abstract}

Material \& Methods: In this prospective study, venous blood samples of consecutive 200 pregnant women in second or third trimester of pregnancy were included and their haematological and serum vitamin $B 12$ were determined including blood complete picture.

Results: Mean $\pm S D$ age of the subjects was 21.54 years $(S D=2.73)$. It was found that 72 had anemia. 25 $(12.5 \%)$ women had vitamin B 12 levels below $647 \mathrm{pg} / \mathrm{ml}$ and were thus included. 37 had iron deficiency anaemia as their ferritin and iron levels were low and were thus excluded from the study. Significant correlation was seen between serum vitamin B 12 and Hb, PCV and MCHC. MCV and RDW did not show any significant correlation with vitamin $B 12$ levels.

Conclusion: We could not establish a statistical correlation between the all important MCV and vitamin B12 because it may be normal in combined deficiency of iron and vitamin B12/folate or even in sublinical vitamin $B 12$ deficiency. There is an urgent requirement to develop a non expensive marker to screen out patients of vitamin B12 deficiency as repeated vitamin B12 level estimation is expensive and cannot be affordable to majority in developing countries. Also, there is requirement to lay down reference values for vitamin $B 12$ during various phases of pregnancy.

Keywords: Vitamin B 12, Red Cell Indices, pregnancy.

\section{Introduction}

Globally around $41.8 \%$ of the pregnant women are anaemic ${ }^{[1]}$. Nutritionally, iron deficiency is the main cause of anemia throughout the world during pregnancy. Folate and vitamin B12 deficiencies are the second most common cause of anemia after iron deficiency ${ }^{[2]}$. 
Centers for Disease Control and Prevention (CDC) has defined anemia in pregnancy as haemoglobin $(\mathrm{Hb})$ level of less than $11 \mathrm{~g} / \mathrm{dL}$ during the $\mathrm{I}^{\mathrm{st}}$ and $\mathrm{III}^{\mathrm{rd}}$ trimesters and less than 10.5 $\mathrm{g} / \mathrm{dL}$ during the $\mathrm{II}^{\text {nd }}$ trimester $^{[3]}$. The lower cut-off is due to haemodilution in pregnancy as plasma volume expands upto $30-40 \%$ as compared to 20 $25 \%$ increase in red cell mass. This causes dilutional drop in $\mathrm{Hb}$ concentration creating a low viscosity state facilitating oxygen transport to the tissues including placenta. However, in India and most of the other developing countries the lower limit for $\mathrm{Hb}$ is often accepted as 10 gm per $\mathrm{dL}^{[4]}$. Also, there occurs physiological macrocytosis with average red cell size increase of $4 \mathrm{fL}$ at term $^{[5]}$.

Vitamin B12 and folate due to its role in DNA synthesis and cell replication, it is considered essential for fetal growth and development ${ }^{[6]}$. Maternal vitamin B12 deficiency has been associated with increased risk of pregnancy complications, including spontaneous abortion, low birth weight, intrauterine growth restriction and neural tube defects ${ }^{[7]}$. Children born to vitamin B12-deficient women are at increased risk for developmental abnormalities and anaemia ${ }^{[8]}$. In a recent study in India, daily maternal vitamin B12 supplementation (50 $\mu \mathrm{g} /$ day $)$ during pregnancy through 6 weeks postpartum substantially improved maternal vitamin B12 status and increased breast milk and infant plasma vitamin B12 $^{\text {concentrations }}{ }^{[9]}$.

The estimation of vit B 12 or folate is expensive and cannot be routinely done in all cases especially in developing countries. Therefore, surrogate markers need to be identified in women who require supplementation. It is also necessary to determine the utility of red cell indices in diagnosing their deficiency during pregnancy. This study was therefore done to ascertain utility of economical red cell indices to determine vitamin B 12 deficiency in pregnant women in India and to compare these to the established norms so as to determine whether the norms apply or whether there is a need to establish local and population specific norms.

\section{Material and Methods}

200 consecutive pregnant women in the second and third trimester (12-40 wks) were enlisted for this study. 25 non pregnant age matched healthy controls were also taken. Informed consent and Institutional ethical clearance was obtained.

Blood samples were collected EDTA $(2 \mathrm{ml})$ and sterile vacutainer $(3 \mathrm{ml})$. The EDTA anticoagulated sample was used for estimation of $\mathrm{Hb}$ and the red cell indices on Sysmex KX-21 three part semiautomated hematology cell counter. $\mathrm{Hb}$, mean corpuscular volume (MCV), mean corpuscular hemoglobin concentration (MCHC), packed cell volume (PCV), red cell distribution width -standard deviation (RDW-SD) were tabulated. Wherever necessary, peripheral smear was seen to subtype the anemia. The serum was separated from the sample in sterile tube. Vitamin B 12 levels were estimated on automated chemiluminescence immune analyzer Roche (Hitachi) cobas e 411 using cobas kits. Value less than $182 \mathrm{pg} / \mathrm{ml}$ was considered as cut off. Simultaneous measurements of serum ferritin and iron were done and cases having concomitant deficiency were excluded.

Data was analyzed using Statistical Package for Social Sciences, version 15.0. Scatter plots were constructed between serum Vitamin B 12 and $\mathrm{Hb}$, MCV, MCHC, PCV and RDW-SD\%.

\section{Results}

The mean age of 200 consecutive pregnant women in second and third trimester of pregnancy was 21.54 years $(\mathrm{SD}=2.73)$. As per $\mathrm{CDC}$ recommendation, a cut-off of $\mathrm{Hb}$ of $10.5 \mathrm{~g} / \mathrm{dL}$ and $11 \mathrm{~g} / \mathrm{dL}$ in $2 \mathrm{nd}$ and $3 \mathrm{rd}$ trimester respectively for anemia were considered and ferritin $<12 \mathrm{ng} / \mathrm{mL}$ were taken for presence of iron deficiency. It was found that 72 had anemia. 37 had iron deficiency anaemia as their ferritin and iron levels were low and were thus excluded from the study. 25 (12.5\%) women had vitamin B 12 levels below 
$182 \mathrm{pg} / \mathrm{ml}$ and had normal serum ferritin and iron levels, were included.

The mean, median mode and $\mathrm{SD}$ of all $\mathrm{Hb}$, red cell indices and serum vitamin B 12 of all cases were calculated. Significant correlation was seen between serum vitamin B 12 and $\mathrm{Hb}$ (Pearson's Corr coeff $(\mathrm{r})=0.272)($ table 1$)$ and PCV (Pearson's Corr coeff $(r)=0.271)$ (table 2). MCHC (Pearson's Corr coeff $(\mathrm{r})=0.198), \mathrm{p}=$ 0.004) (table 3). MCV (Pearson's Corr coeff $(\mathrm{r})=$ - 0.183) (table 4), and RDW (Pearson's Corr coeff $(r)=-0.229)$ (table 5) did not show any significant correlation with vitamin B 12 levels.

We attempted to correlate between serum vitamin B 12 and red cell indices to see if any index can predict the presence of sub-clinical serum vitamin B 12 deficiency in this group but no significant correlation was found.

Table 1 Correlation between Vitamin B 12 and $\mathrm{Hb}$

\begin{tabular}{|l|c|c|c|}
\hline \multirow{2}{*}{ Vit B12 } & \multicolumn{2}{|c|}{ Haemoglobin } & \multirow{2}{*}{ Total } \\
\cline { 2 - 3 } & $<11 \mathrm{gm} / \mathrm{dl}$ & $\geq 11 \mathrm{gm} / \mathrm{dl}$ & \\
\hline$<182 \mathrm{pg} / \mathrm{ml}$ & $2(8)$ & $23(42)$ & 25 \\
\hline Total & 2 & 23 & 25 \\
\hline
\end{tabular}

Pearson's correlation coefficient $=0.272$

Table 2 Correlation between Vitamin B 12 and PCV

\begin{tabular}{|l|c|c|c|c|}
\hline \multirow{2}{*}{ Vit B12 } & \multicolumn{3}{|c|}{ PCV } & \multirow{2}{*}{ Total } \\
\cline { 2 - 4 } & $<60 \mathrm{fl}$ & $60-92 \mathrm{fl}$ & $\geq 92 \mathrm{fl}$ & \\
\hline $\begin{array}{l}<\quad 182 \\
\mathrm{pg} / \mathrm{ml}\end{array}$ & $25(100)$ & 0 & 0 & $25(100)$ \\
\hline Total & $25(100)$ & 0 & 0 & $25(100)$ \\
\hline
\end{tabular}

Pearson's correlation value $=0.271$

Table 3 Correlation between Vitamin B 12 and $\mathrm{MCHC}$

\begin{tabular}{|l|c|c|c|c|}
\hline \multirow{2}{*}{ Vit B12 } & \multicolumn{3}{|c|}{ MCHC } & \multirow{2}{*}{ Total } \\
\cline { 2 - 4 } & $\begin{array}{c}<20 \\
\mathrm{gm} / \mathrm{dl}\end{array}$ & $\begin{array}{c}20-33 \\
\mathrm{gm} / \mathrm{dl}\end{array}$ & $\begin{array}{c}\geq 33 \\
\mathrm{gm} / \mathrm{dl}\end{array}$ & \\
\hline$<182 \mathrm{pg} / \mathrm{ml}$ & 0 & $25(100)$ & 0 & $25(100)$ \\
\hline Total & 0 & $25(100)$ & 0 & $25(100)$ \\
\hline
\end{tabular}

Pearson's correlation value $=0.198$

Table 4. Correlation between Vitamin B 12 and $\mathrm{MCHC}$

\begin{tabular}{|l|l|l|l|l|}
\hline \multirow{2}{*}{ Vit B12 } & \multicolumn{3}{|l|}{ MCV } & \multirow{2}{*}{ Total } \\
\cline { 2 - 4 } & $<76 \mathrm{fl}$ & $76-96 \mathrm{fl}$ & $\geq 96 \mathrm{fl}$ & \\
\hline$<182 \mathrm{pg} / \mathrm{ml}$ & 0 & $15(60)$ & $10(40)$ & $25(100)$ \\
\hline Total & 0 & 15 & 10 & \\
\hline
\end{tabular}

Pearson's correlation value $=-0.183$
Table 5 Correlation between Vitamin B 12 and $\mathrm{MCHC}$

\begin{tabular}{|l|c|c|c|}
\hline \multirow{2}{*}{ Vit B12 } & \multicolumn{2}{|c|}{ RDW } & \multirow{2}{*}{ Total } \\
\cline { 2 - 3 } & $<54 \mathrm{fl}$ & $\geq 54 \mathrm{fl}$ & \\
\hline$<182 \mathrm{pg} / \mathrm{ml}$ & $17(68)$ & $8(32)$ & 25 \\
\hline Total & 17 & 8 & 25 \\
\hline
\end{tabular}

\section{Discussion}

Anaemia in pregnancy is due to increased demand coupled with poor diet and many other reasons. A blood complete picture helps in evaluation and investigation of anaemia ${ }^{[10]}$. Mean Corpuscular Volume (MCV) in particular is of profound significance as it can help in identifying the cause of anaemia and is very cost effective. A low MCV is suggestive of iron deficiency anemia and raised MCV suggests vitamin B12 or folate deficiency. It is common practice that serum vitamin B12 and serum folate or red cell folate are estimated to confirm megaloblastic anemia. The levels of these are expected to be lower in such cases. Red cell folate is a more reliable maker than serum folate [11].

A normal MCV, however, is considered to imply that there is neither iron deficiency nor vitamin B12/ folate deficiency. On the contrary, apart from normal cases, MCV within its normal reference range can also occur in cases of combined mixed nutrient deficiencies ${ }^{[4,5]}$. Patients having deficiency of iron as well as vitamin B12/ folate exhibit an MCV lying within its normal range. Here RDW helps us in that if RDW is raised, it reflects anisopoikilocytosis and therefore smear examination is mandated ${ }^{[12,13]}$. Serum ferritin, vitamin B12 and red cell folate status can also be assessed and timely managed to avoid both maternal and foetal hazards ${ }^{[14,15]}$.

Cross-tabulation between the vitamin B12 and hemoglobin, PCV and MCHC was statistically significant in our study. However, negative correlation was seen in relation to MCV. This difference is attributed to the normal MCV values in patients with subclinical low ferritin, perhaps due to mixed micro nutrient deficiency ${ }^{[16]}$. As 
ferritin is also an acute phase reactant ${ }^{[17]}$, it may have been falsely elevated, thus rendering a bias.

Studies conducted in general Indian population suggested up to $52 \%$ prevalence of vitamin B12 deficiency but only $2.4 \%$ of anemic patients to have increased MCV showing macrocytic picture, but surprisingly no studies report it during pregnancy. It is probably due to high prevalence of iron deficiency giving a picture of mixed deficiency anemia, thereby showing a normal MCV. ${ }^{[18]}$

Several studies suggested that vitamin B-12 status in women in resource-limited countries is poor. Among 113 Guatemalan women, plasma vitamin B-12 was deficient or low in nearly $50 \%$, and breast milk vitamin B-12 concentration was low in $31 \%,{ }^{[19]}$. In another study from Mumbai, mean plasma vitamin B-12 in pregnant non anemic women was 50.2 vs. $131.3 \mathrm{pmol} / \mathrm{L}$ in non pregnant women $(\mathrm{P}<0.001)^{[9,20]}$. Of note, vitamin $\mathrm{B}-12$ concentrations in all of the groups reported in these studies were generally low.

A study carried out in Venezuela, showed prevalence of folic acid and B12 deficiency in pregnant women of up to $36.32 \%$ and $61.34 \%$. In this study the overall prevalence of severe anemia was $1.2 \%$, out of which $41.6 \%$ of patients had macrocytic anemia ${ }^{[21]}$.

It is poignant to note that, there are no different vitamin B 12 reference levels for pregnant women Several studies suggest that reference values for non pregnant women are not suitable for assessing vitamin B12 status during pregnancy, implying the need for reference values related to specific stages of pregnancy ${ }^{[12,22]}$.

\section{Conclusion}

MCV may be normal in combined deficiency of iron and vitamin B12/ folate or even in sublinical vitamin B12 deficiency. Therefore, it is essential that pregnant women with normal MCV should be screened for mixed deficiency anemia and further evaluation. There is an urgent need to develop a non expensive and readily accessible marker to screen out patients of vitamin B12 deficiency as repeated vitamin B12 level monitoring is expensive and cannot be affordable to majority in developing countries. Also, there is requirement to lay down reference values for vitamin B 12 during various phases of pregnancy.

\section{Source of Funding: None}

Conflict of Interests: All authors have none to declare

\section{References}

1. World Health Organization. Worldwide prevalence of anemia 1993-2005. WHO global database on anemia. Geneva, World Health Organization. 2008.

2. Chandyo RK, Ulak M, Kvestad I, Shrestha M, Ranjitkar S, Basnet S et al. The effects of vitamin B12 supplementation in pregnancy and postpartum on growth and neurodevelopment in early childhood: Study Protocol for a Randomized Placebo Controlled Trial. BMJ Open 2017;7: e016434. doi:10.1136/bmjopen-2017016434.

3. CDC criteria for anemia in children and childbearing-aged women. MMWR Morb Mortal Wkly Rep. 1989;38:400- 404.

4. Rigvardhan, Vinod Raghav, Rakhi Negi, Punyashlok Biswal, Y S Rana. Correlation of serum ferritin with red cell indices and hemoglobin in indian women in second and third trimester of pregnancy. International Journal of Contemporary Medical Research 2016;3(10):3069-3072.

5. Cuervo LG, Mahomed K. Treatments for iron deficiency anemia in pregnancy (cochrane review). Issue 4. In: The Cochrane Library, vol. 80(1). Chichester, UK: John Wiley and Sons, Ltd (Level I); 2003:92.

6. Bhargava M, Iyer PU, Kumar R, Ramji S. Relationship of maternal serum ferritin with foetal serum ferritin, birth weight and 
gestation. J Trop Pediatr 1991; 37(4): 14952

7. Dwarkanath P, Barzilay JR, Thomas T, et al. High folate and low vitamin B-12 intakes during pregnancy are associated with small for-gestational age infants in South Indian women: a prospective observational cohort study. Am J Clin Nutr 2013;98:1450-8.

8. Pepper MR, Black MM. B12 in fetal development. Semin Cell Dev Biol 2011;22:619-23.

9. Duggan $\mathrm{C}$, Srinivasan K, Thomas T, et al. Vitamin B-12 supplementation during pregnancy and early lactation increases maternal, breast milk, and infant measures of vitamin B-12 status. J Nutr 2014;144:758-64.

10. Sachdev H,Gera T, Nestel P. Effect of iron supplementation on mental and motor development in children: systematic review of randomised controlled trials. Public Health Nutr. 2005;8(2):117-32

11. Refsum H, Yajnik CS, Gadkari M . Hyperhomocysteinemia and elevated methylmalonic acid indicate a high prevalence of cobalamin deficiency in Asian Indians. Am J Clin Nutr 2001; 74 : 233-41.

12. Koebnick C, Heins UA, Dagnelie PC, Wickramasinghe SN, Ratnayaka ID, Hothorn $\mathrm{T}$ et al. Longitudinal Concentrations of Vitamin B12 and Vitamin B12-binding Proteins during Uncomplicated Pregnancy. Clinical Chemistry 2002; 48:928-933.

13. Salvador Villalpando. Discussion: Effects of folate and vitamin B12 deficiencies during pregnancy on fetal, infant, and child development. Food and Nutrition Bulletin 2008; 29: S112-S115.

14. Rumbold A, Middleton P, Crowther CA. Vitamin supplementation for preventing miscarriage. Cochrane Database Syst Rev 2005;18;(2):CD004073.

15. Puri M, Kaur L, Walia GK, Mukhopadhhyay R, Sachdeva MP, Trivedi SS, Ghosh PK, Saraswathy KN. MTHFR C677T polymorphism, folate, vitamin B12 and homocysteine in recurrent pregnancy losses: a case control study among north Indian women. J Perinat Med. 2013; 41:549-54.

16. Tiwari M, Kotwal J, Kotwal A, Mishra P, Dutta V, Chopra S. Correlation of hemoglobin and red cell indices with serum ferritin in Indian women in second and third trimester of pregnancy. http://dx.doi.org/10.1016/j.mjafi.2012.07.0 16

17. Crichton RR. The biochemistry of ferritin. Br J Haematol. 1992;26:677-681

18. Khanduri U and Sharma A. Megaloblastic anemia- prevalence and causative factor. Natl Med J India 2007; 20: 172-75

19. Casterline JE, Allen LH, Ruel MT. Vitamin B-12 deficiency is very prevalent in lactating Guatemalan women and their infants at three months postpartum. J Nutr. 1997;127:1966-72.

20. Jathar VS, Inamdar-Deshmukh AB. Erythrocyte vitamin B12 activity in lactovegetarian pregnant Indian women. Acta Haematol. 1981;65:153-6.

21. Garcia-Casal MN, Osorio C, Landaeta M . High prevalence of folic acid and B12 deficiency in infants, children, adolescents and pregnant women in Venezuela. Eur $\mathbf{J}$ Clin Nutr 2005; 59: 1064-70.

22. Pardo J, Peled Y, Bar J, Hod M, Sela BA, Rafael ZB, et al. Evaluation of low serum vitamin B12 in the non-anaemic pregnant patient. Hum Reprod 2000;15:224-6. 